\title{
Design and Application of Games in College English Classroom Teaching ${ }^{\mathrm{i}}$
}

\author{
Qu Jiangli ${ }^{1, *}$, Zhou Shuang ${ }^{1}$, Bai Xiaoge ${ }^{2}$ \\ ${ }^{1}$ School of Foreign Studies, Northwestern Polytechnical University, China \\ ${ }^{2}$ Library, Northwestern Polytechnical University, Xi'an, China
}

Received August 23, 2019; Revised September 19, 2019; Accepted September 26, 2019

Copyright $(2019$ by authors, all rights reserved. Authors agree that this article remains permanently open access under the terms of the Creative Commons Attribution License 4.0 International License

\begin{abstract}
College English teaching games are particularly interesting and interactive, which can stimulate college students' motivation and drive for English learning effectively. In the meantime, this kind of activity solidifies students' self-confidence to learn English and dispels psychological stress and anxiety as well, so as to optimize the efficiency of English learning. This paper summarizes the basic principles, which should be followed, and offers the specific methods and items we should pay attention to in view of the game design and application in college English classroom teaching. The thesis is based on the relevant research achievements of the predecessors, and several examples are listed according to the practice experience, such as words solitaire, sentences renewing and reciting, class discussions, debates, role playing, etc. The practice indicates that his kind of classes is being longed for and unforgettable if we can both successfully cultivate the students' capability in cross-culture communication and influence their learning and life.
\end{abstract}

Keywords College English, the Teaching Games, Design, Application

\section{Introduction}

English teachers in China have accumulated rich experiences in teaching over the years. Continuous development and improvement of English class teaching methods have been made, during which some achievements have been gained. But how to juggle all the learners in English classroom teaching, raise students' attention in classroom, teach according to their aptitude, these are always difficult problems in the design of English teaching [1]. In order to adapt to the needs of English classroom teaching reform in the new period, a lot of English teachers have been taken a variety of teaching methods to strengthen enjoyment in English classroom teaching, and games are regarded as the most effective one. Practice has proved that classroom teaching will become more colorful within the application of games. Compared with boring, mechanical learning process under the traditional mode, games can reflect enjoyment and interaction in language learning.

In recent years, the gaming teaching method has been widely applied in primary and secondary school education. However, according to the author, college English teachers didn't put enough emphasis on design and application of games, which actually ignored the actual state of college students today and their psychological demand. A survey found that most college students hope that they can acquire English reading, writing and oral skills in a relaxing and happy atmosphere. The author thinks if teachers can blend various games with rich cultural knowledge in English, it will make college English classroom learning more fun, so that students' fear in learning can be overcome under the lead of great interest and the quality and efficiency of English learning can be improved.

\section{Issues Should Be Considered in Game Design and Application in College English Teaching}

\subsection{Basic Principles of Game Design and Application in College English Teaching}

\subsubsection{Interest}

Interest is one of the most important principles in college English classroom teaching [2]. Since the ancient time of China, interest has been an important thought in education. Lacking of interest in classroom learning, students' learning efficiency will be decreased. Therefore, if there are games introduced in the teaching process as 
supplementary means, students' learning drive will be stimulated.

\subsubsection{Purpose}

Games are only a supplementary means in college English teaching, which should correspond to the emphasis and difficulties in classroom teaching. The content and form of games should be set according to corresponding language skills; the degree of difficulty should also be set corresponding to learners' English language ability [3].

\subsubsection{Diversity}

If the same game, even in different forms, being played repeatedly in class, learners will get bored soon. Therefore, college English teachers should accumulate new experiences, collect new games and forms, to make games in class diversified.

\subsubsection{Competition}

In order to attract students by using games in classroom, some competitive games should be designed. The purpose is to fully mobilize the enthusiasm of students and to make them participate in the activities full of passion with the eager to win.

\subsubsection{Fairness}

The design and application of games should be suitable to all students. Equal or even more opportunities should be offered the lower-level group. In order to avoid losing enthusiasm and confidence in participation, this group of students should be taught step by step with easy parts.

\subsection{General Ways in Game Design and Application in College English Classroom Teaching}

\subsubsection{Design and Application of Card Games}

One of relatively commonly used ways in English class is traditional card game, which is effective in teaching pronunciation, vocabulary, sentence structure, grammar, etc.[4]. It was proved to be significantly effective. In fact, card game and word guessing game work together, too. We can divide students into several groups; representative of each group stands in front facing the class. What the teacher should do is to show the person a card with word on it, and the person's task is to explain the word by action, sound or in English words or sentences, but not the word on the card. Then other classmates will make a prompt answer according to the information received. Teachers can give each group 5 or more cards, and the group which guessed all the words right with the shortest time wins the game.

\subsubsection{Design and Application of Puzzle Games}

Puzzle games are beneficial in vocabulary, sentence patterns, reading and memory training practice [5]. Design of these games is always correlated to graphics, puzzles, etc. so as to have word memorizing, sentence-making, sentence pattern transformation, etc. For example, learners can watch a video clip or read some writing materials on the purpose of developing insights on the given sentence patterns, paragraphs or passages.

\subsubsection{Design and Application of Situational Games}

English teachers often use situational teaching method in teaching, which can be extended to a classroom game. For example, the background can be set beforehand, learners will express the knowledge points by performing, imitating, etc., through which learners' listening, speaking and comprehensive ability can be improved quickly. Situational games include theatrical performing, poetry reading, debating, speech delivering, report writing, etc. [6]. In such games, a task should be given and the form should be chosen by the teacher. These games are especially effective in listening practice. Learners can feel the real language environment and use English more flexibly.

\subsection{Precautions in Design and Application of Games in College English Teaching}

\subsubsection{Games Should Be Used in Appropriate Time in Classroom Teaching Process}

Specific teaching task of college English course demands teachers to carry out games timely as a supplementary means [7]. Teachers should insure the quality of classroom teaching first. Therefore, according to specific teaching tasks and different periods, games are divided into lead-in, in-class, after-class practice, etc. In other words, it's important to choose appropriate time to play games. Usually, games are used at the beginning of a class to raise students' attention, which is also called warming up. They can also be played in the middle of the class, before students get tired. The purpose is to improve learning efficiency, which is called waking up in English teaching.

\subsubsection{The Design of Games Should Match the Learners' English Level}

Students should push themselves beyond the unknown limits while keeping positive learning motivation and attitude. Therefore, the form and content of games should be in accordance with college students' characteristics, psychological characteristics and learning progress.

\subsubsection{The Design of Games Should Match the Teaching Purpose in College English Education}

The design of games should be aimed at specific teaching tasks, and be correspondence to training of language skills. In order to reinforce the language points and skills students have learnt in English classroom teaching, the task and plot of games should be used flexibly to consolidate the various tasks in the process. 


\subsubsection{The Design of Games Should Reflect the Step-by-step Teaching Principle}

College English teachers should guide all students step by step, so that they can be fully involved in games. As to game design and application, there should be tips related to fixed language points or skills in the gaming process, so that games can go smoothly and teaching aims can be achieved successfully.

\subsubsection{The Design of Games Should Take Cultural Elements into Consideration}

Chinese students are interested in western culture, including their places of interest, festivals, diet and so on. If teachers can involve various cultural elements in gaming process, making students complete the corresponding learning tasks as well as bearing cultural connotation of English language in mind, the learning efficiency will be surely improved.

\section{Conclusions}

In cross-cultural communication, it's easy for college students to have psychological stress and anxiety. Practice has proved that games can effectively enhance college English teaching efficiency in a relaxing, fun gaming environment. Based on specific teaching tasks, college English teachers should involve more cultural elements in forms and content of games, so to arouse students' enthusiasm in game participation and classroom interaction. In this way, the quality and efficiency of college English teaching can be achieved successfully.

\section{REFERENCES}

[1] Bai Lin. The Design and Application of Games in College Oral English Class. [J].Brilliant Writing, 2009(19): 61-62.

[2] Wang Weiqing. The Tactics of Game and College English Teaching [J]; Journal of Wuhan Metallurgical Manager's Institute, 2004-03.

[3] Zhou Yanfang. The Application of Games in College English Education [J]. Scientific and Technological Information, 2010 (13): 208-209.

[4] FanWenfang. Games in Classroom and College English Teaching [J]. Journal of Hetian Teachers College (Chinese (4): Version), 2010165-166.

[5] Wen Ximei. An Analysis of the Application of Game Teaching Method Based on Emotional Perspective in English Teaching in Higher Vocational Colleges [J]. Overseas English, 2010 (10): 155+159.

[6] Zeng Yan. Studies on Vocational College English Classroom Games Based on Textbook. Journal of Wuhan Institute of Shipbuilding Technology, 2011-01.
[7] Liu Shuang. The Magic Tool to Rescue English Class in College---Game Teaching Method. [J]. Research on Curriculum Education, 2013 (1): 249.

[8] Zhu Wen. Practical Exploration of English Classroom Game Teaching Method [J]. New Course (Part II), 2006 (6): 69-70.

\footnotetext{
The paper is sponsored by Cultivating International Talents and Constructing an Informatization Teaching Ecological System -- An Exploration on the College English Teaching Reform , Key Teaching Reform Project of Northwestern Polytechnical University（对标国际化 人才培养, 构建信息化教学生态体系--大学英语教改探索 西北工业 大学教改重点项目)
} 